Egypt. Acad. J. biolog. Sci., 1 (1): 37-43 (2009)

Email: egyptianacademic@yahoo.com

Received: 7/9/2009
B. Zoology

ISSN: 2090 - 0759

www.eajbs.eg.net

\title{
Survey, population dynamics and importance value of certain land snail species infesting different crops in sharkia governorate
}

\author{
Sebay Z. S. Shetaia; Shehate A. A. Ismail and Samah M. Abdel-Kader \\ Plant Protection Reasearch Institute, Agric. Res. Center Dokki, Giza, Egypt.
}

\section{ABSTRACT}

Survey, population dynamics and importance value of certain land snail species infesting some vegetable and field crops as well as fruit trees ware determined at some localities in Sharkia Governorate. Results revealed that the glassy clover snail Moncha. cartusiana (Muller) and the amber snail, Succinea. putris (linues) were surveyed at Awlad- Sakr and Abo-Kapeer counties. M. cartusiana snails were found with higher density than $S$. putris. The majority of the examined crops were found with heavy infestation with $M$. cartusiana snail while $S$. putris were recorded with moderate or light infestation in the examined localities. Regarding population dynamics, it found that $M$. cartusiana snail was recorded with high density at the tested winter crops during spring months (March, April and May) as compared with winter or autumn months. Finally, when importance value was determined, it found that frequency occurrence and population density gave different results. The land snail species can be arranged descedingly,according to its importance values as follow: $E$. vermiculata $>, M$. cartusiana $>$, C. acuta, $>H$. vestalis. It may be useful to combine frequency of occurrence, population density and biomass in the form of importance value.

\section{Keywords: Survey, land snail, Sharkia}

\section{INTRODUCATION}

Molluscs are considered as a group of serious pests attacking agricultural crops around the world. Land gastropods cause costly damage to field crops, vegetables and fruit trees as well as ornamental plants. In addition, some gastropods work as intermediate hosts for many parasitic worms infesting man and his domestic animals (Godan, 1983 and Barker, 2002).

Economic serious mollusces has been recorded recently in Egypt (Kassab and Daoud, 1964; El-Okda, 1984 and El-Deeb et al. 1999). Occurrence, population dynamics and damage caused by such land snail gastropods in Sharkia Governorate has been investigated. (Ghamry et al., 1993; Arafa, 1997; El-Masry, 1997; Ismail, 1997; Mahrous et al., 2002; Lokma, 2007 and Abdel-Aal, 2007).

The cornerstone of any pest management depends mainly on information about its ecology and biology. The main aims of these studies were to get more information about survey, population dynamics and importance value of the land snail species in different Sharkia Governorate localities.

\section{MATERIAL AND METHODS}

\section{1- Survey of land snails on different crops at Sharkia Governorate.}

A survey was conducted to study the distribution and population density of land snail species attacking some host plants cultivated in two localities two 
(counties) of Sharkia Governorate during the period from Sept. 2007 to Aug. 2008. These counties and localities were: Abo-Kapeer (Kafr-Elbaz and Al-Abazia) and Awlad Sakr (Bani-Hassan and Bani-Mansour). The survey included field crops (i.e. broad bean, Egyptian clover, wheat, maize, and cotton), vegetable crops (i.e. pea, egg plant, cabbage, tomato and lettuce) and fruit crops (i.e. mango and navel orange). Samples were taken from each crop area by using the quadrate sample size $50 \times 50$ $\mathrm{cm}$ (Staikou and Lazaridou 1990).

Snails from each host plant in each surveyed areas were transferred in muslin cloth bags to the laboratory and identified according to the keys given by Godan (1983).

\section{2- Population dynamics of Monacha cartusiana (Muller) on certain field crops, vegetables and navel orange trees.}

The seasonal population dynamics of the predominant glassy clover land snails $M$. cartusiana were studied at Awlad-Sakr county during two successive growing seasons (2007/2008 and 2008/2009). Certain field crops (i.e. Egyptian clover, wheat, and broad bean; vegetable crops as pea, cabbage and lettuce) and navel orange as fruit crop were chosen for this study. An area of about one feddan was selected for each crop. Five replicates of quadrate sample size $(50 \times 50 \mathrm{~cm})$ were randomly examined biweekly during the growing season of each crop except navel orange which continued for 12 months. Examination was conducted during early morning before sunrise. All snails found on either plants or soil surface in the quadrate were counted and left in their initial places (Baker, 1988). Data concerning temperature and relative humidity during the period of study were obtained from metrological station of Abo-Kapeer. The obtained data were subjected to statistical analysis as correlation coefficient between snails population and each of temperature and relative humidity according to Costat (2005).

\section{3- Importance value of herbivorous snails estimates:}

A citrus orchard about 200 hectars located at Inshas county, Belbeis district, Sharkia Governorate was selected to measure some ecological parameters (i.e. frequency occurrence, population density and importance value).

A total of 105 samples were tested in such orchard during the activity period from Feb. 2007 to May 2008. All surveyed snails were counted and classified to their species according to the key given by Godan (1983). Ten adult snails from each identified species were weighted and the average biomass for each species was calculated. Importance values of land snail species were determined according to Norton (1978) as follows:

$$
\begin{aligned}
& \text { Absolute frequency occurrence }=\frac{\text { Number of sample containing a species }}{\text { Number of samples examined }} \times 100 \\
& \text { Relative frequency occurrence }=\frac{\text { Absolute frequency occurrence of species }}{\text { Sum of frequency occurrence of all species }} \times 100
\end{aligned}
$$

Absolute density $=\frac{\text { Total number of individuals of a species }}{\text { Number of samples containing this species }}$

Relative density $=\frac{\text { Number of individuals of a species }}{\text { Sum of individuals of all species }} \times 100$

Absolute biomass $=$ Weight of snail within its shell.

Relative biomass $=\quad \frac{\text { Absolute biomass of a species }}{\text { Sum of biomass of all species }} \times 100$ 
Importance value $=$ Relative frequency + Relative density + Relative biomass

\section{RESULTS AND DISCUSSION}

\section{1- Survey studies:}

A survey studies were carried out on molluscs fauna infesting different crops at two districts of Sharkia Governorate. Results presented in Table (1) revealed that the two species of herbivorous land snails were found on different host plants at Awlad-Sakr and Abo-Kapeer counties. These species were the glassy clover snail, $M$. cartusiana and the amber snail, Succinea putris (Linnaeus). The identified species varied in their incidence and level of infestation according to the locality and the host type. It is obvious that $M$. cartusiana represented the highest incidence compared to the other species, since it was recorded in all hosts. Generally, the listed hosts can be classified into three categories according to the degree of infestation with $M$. cartusiana.

Table (1): Survey of land snails on different crops at certain districts in Sharkia Governorate.

\begin{tabular}{|c|c|c|c|}
\hline District & Village & Snail species & Host plant and level infestation \\
\hline Awlad-Sakr & $\begin{array}{l}\text { Bani-Hassan and } \\
\text { Bani-Mansour }\end{array}$ & M. cartusiana & $\begin{array}{l}\text {-Broad bean }(++) \text {, Clover }(+++) \text {, Wheat }(++) \text {, Cotton } \\
(+) \text {, eggplant }(+) \text {, Pea }(+++) \text {, Cabbage }(+++) \text {, Lettuce } \\
(+++) \text {, Grapes }(+++) \text {, Orange }(+++) .\end{array}$ \\
\hline Abo-Kapeer & $\begin{array}{l}\text { Alabzia and } \\
\text { Kafr-Elbaz }\end{array}$ & $\begin{array}{l}\text { M. cartusiana } \\
\text { S. putris }\end{array}$ & $\begin{array}{l}\text {-Broad bean }(+) \text {, Clover }(+++) \text {, Wheat }(++) \text {, Maize } \\
(+) \text {, Cotton }(+) \text {, eggplant }(++) \text {, Tomato }(++) \text {, Pea } \\
(+++) \text {, Cabbage }(+++) \text {, Lettuce }(+++) \text {, Mango }(++) \text {, } \\
\text { Orange }(+++) \text {. } \\
\text {-Brood bean }(+) \text {, Clover }(++) \text {, Wheat }(+) \text {, Maize } \\
(++) \text {, Cotton }(+) \text {, eggplant }(+) \text {, Tomato }(+) \text {, Pea }(+) \text {, } \\
\text { Cabbage }(+) \text {, Lettuce }(++) \text {, Mango }(+) \text {, Orange }(+) .\end{array}$ \\
\hline
\end{tabular}

$(+)=$ light infestation (less than 15 snail $\left./ 0.25 \mathrm{~m}^{2}\right)$

$(++)=$ Moderate infestation (bettwen $16-30$ snails $/ 0.25 \mathrm{~m}^{2}$ )

$(+++)=$ heavy infestation (more than 30 snails $/ 0.25 \mathrm{~m}^{2}$ )

These categories were heavy, moderate and light infestation. The majority of the examined crops were found with heavy infestation especially Egyptian clover, pea, cabbage, lettuce, grapes and navel orange. Broad bean, wheat, tomato and mango were detected with moderate infestation. Cotton, maize, eggplant and broad bean were found with light infestation at Awlad-Sakr and Abo-Kapeer counties. Regarding $S$. putris it was detected only at Alabzia and Kafr-ELbaz belonging to Abo-Kapeer with moderate or light infestation. For instance, it was recorded with moderate infestation at Egyptian clover, maize and lettuce. It was recorded on broad bean, wheat, egg plant, cotton, tomato, pea, cabbage, mango and navel orange with light infestation.

Many authors recorded that land snails act as a dangerous pest to agricultural crops at different Governorates in Egypt. In Sharkia Governorate terrestrial snails were found in different districts attacking many economic crops for instances, $M$. cartusiana, S. putris were recorded in Awlad-Sakr and Abo-Kapeer districts (AbdelAal, 2001). These results are in harmony with those reported by many investigators who surveyed land snails in Sharkia Governorate (Ghamry et al. 1993; Arafa, 1997; El-Masry, 1997; Ismail, 1997and Hegab et al. 1999). 


\section{2- Population dynamics of $M$. cartusiana on certain field, vegetable, and fruit crops at Awlad-Sakr County.}

The survey study revealed that $M$. cartusiana was the predominant species with a relatively high numbers on major economic crops. Therefore, population dynamics of this species was studied on Egyptian clover, wheat, broad bean, pea, cabbage, lettuce and navel orange in Bani-Hassan and Bani-Mansour villages, AwladSakr county during two successive growing seasons (2007-2008 and 2008-2009). Resulted presented in Table (2) revealed that the initial infestation of $M$. cartusiana was recorded in Sept. on cabbage and navel orange with a relatively low population densities of $(17.2,16.6)$ and $(17.2,19.8)$ snails per quadrate sample size in the growing season of 2007-2008 and 2008-2009, respectively. On Egyptian clover, pea and lettuce the initial infestation appeared in the beginning of Oct. with low numbers of $(11.8,12.2),(10.4,9.6)$ and $(16.8,17.6)$ snails in the two successive growing seasons, respectively. Moreover, the initial infestation of wheat and broad bean, appeared in Nov. with low numbers of $(5.2,4.4)$ and $(9.2,8.6)$, snails in the two successive growing seasons, respectively. Regarding the behavior of $M$. cartusiana population after the initial infestation appeared, it is clear that the number of snails increased until the end of growing seasons for every crop. The average numbers of snails per sample were $(26.2,27.4)$ and $(19.0,18.4)$ for Egyptian clover and cabbage in Jun. in the two successive growing season and $(21.4,21.8)$ and $(18.2,19.4)$ for wheat and lettuce in May. The snails numbers reached to $(22.0,21.2)$ and $(21.0,23.8)$ snail / sample in Apr. for broad bean and pea, respectively.

Table (2): Population dynamics of M. cartusiana on different crops at Awlad-Sakar district, Sharkia Governorate during 2007 - 2008 \& 2008- 2009 seasons.

\begin{tabular}{|c|c|c|c|c|c|c|c|c|c|c|c|c|c|c|c|c|c|c|}
\hline \multirow{3}{*}{ Date } & \multicolumn{14}{|c|}{ Average romber of $M$ G G } & \multicolumn{4}{|c|}{ Climate fartors } \\
\hline & \multicolumn{2}{|c|}{ Clover } & \multicolumn{2}{|c|}{ Whest } & \multicolumn{2}{|c|}{ Erood beam } & \multicolumn{2}{|c|}{ Pea } & \multicolumn{2}{|c|}{ Cabbage } & \multicolumn{2}{|c|}{ Lettuce } & \multicolumn{2}{|c|}{ Orange } & \multicolumn{2}{|c|}{ Temp. C } & \multicolumn{2}{|c|}{ RH. } \\
\hline & $2007 / 08$ & $2008 \% 09$ & 200708 & 200809 & 200708 & 200809 & $2007 \% 8$ & $2008 \% 09$ & $2007 \% 8$ & 200809 & $2007 / 08$ & $2008 \% 09$ & $2007 \% 8$ & $2008 / 09$ & 200708 & $2008 \pi 9$ & $2007 \% 0$ & $2008 \% 09$ \\
\hline Sep. & - & $\cdot$ & - & - & $\cdot$ & $\cdot$ & $\cdot$ & - & 17.2 & 16.6 & - & - & 17.2 & 19.8 & 25.8 & 26.6 & 39.9 & 37.1 \\
\hline oct. & 11.8 & 12.2 & - & - & $\cdot$ & $\cdot$ & 10.4 & 9.6 & 18.0 & 18.4 & 16.8 & 17.6 & 19.6 & 18.8 & 24.0 & 21.0 & 34.8 & 35.1 \\
\hline Nov. & 14.6 & 15.4 & 5.2 & 4.4 & 9.2 & 8.6 & 18.2 & 16.8 & 20.0 & 18.2 & 20.4 & 19.8 & 19.8 & 27.2 & 21.1 & 18.2 & 50.8 & 36.4 \\
\hline Dec. & 17.8 & 17.2 & $\overline{10.4}$ & 12.2 & 9.8 & 10.0 & 22.0 & 20.8 & 19.6 & 20.0 & 24.2 & 23.6 & 24.2 & 22.0 & 15.5 & 15.7 & 53.8 & 50.2 \\
\hline Jam & 24.2 & 23.2 & 10.8 & 13.2 & 12.0 & 13.2 & 24.0 & 24.4 & 20.2 & 21.2 & 24.0 & 25.2 & 24.6 & 18.2 & 13.9 & 13.1 & 39.6 & 42.7 \\
\hline Fab & 26.0 & 27.6 & 12.0 & 16.4 & $\begin{array}{l}14.6 \\
\end{array}$ & 15.4 & 26.8 & 28.2 & 22.0 & 20.4 & 26.2 & 28.4 & 26.0 & 22.8 & 14.1 & 14.4 & 35.5 & 40.1 \\
\hline Mar. & 30.4 & 31.4 & 18.6 & 19.2 & 17.0 & 18.6 & 28.8 & 29.6 & 23.2 & 22.2 & 29.4 & 28.6 & 25.2 & 27.2 & 15.8 & 16.4 & 35.0 & 34.0 \\
\hline Aqr. & 34.6 & 36.8 & 20.2 & 21.4 & 22.0 & 21.2 & 21.0 & 23.8 & 25.0 & 28.0 & 30.0 & 32.2 & 28.6 & 30.0 & 19.6 & 20.2 & 29.4 & 27.2 \\
\hline May & 30.4 & 32.6 & 21.4 & 21.8 & - & $\cdot$ & $\cdot$ & $\cdot$ & 29.2 & 30.6 & 18.2 & 19.4 & 19.2 & 28.8 & 23.7 & 22.5 & 25.8 & 25.7 \\
\hline $\mathrm{rm}$. & 26.2 & 27.4 & $\cdot$ & - & - & - & - & - & 19.0 & 18.4 & $\cdot$ & - & 22.0 & 24.6 & 25.9 & 26.4 & 35.2 & 34.7 \\
\hline Ful. & - & $\cdot$ & - & $\cdot$ & $\cdot$ & $\cdot$ & $\cdot$ & $\cdot$ & $\cdot$ &. & $\cdot$ & $\cdot$ & 21.2 & 22.8 & 28.2 & 26.9 & 44.3 & 42.5 \\
\hline Auz. & - & $\cdot$ & - & - & - & - & - & - & - & $\cdot$ & - & - & 21.8 & 22.6 & 30.1 & 28.6 & 45.6 & 44.5 \\
\hline Tatal & 216.0 & 223.6 & 98.10 & 108.6 & 84.6 & 87.0 & 150.1 & 153.2 & 213.4 & 214.0 & 189.2 & 194.8 & 269.4 & 284.8 & & & & \\
\hline Mesm & 24.0 & 24.8 & 14.0 & 15.5 & $\begin{array}{l}14.1 \\
\end{array}$ & 14.5 & 21.4 & 21.8 & 21.3 & 21.4 & 23.6 & 24.3 & 22.4 & 23.7 & & & & \\
\hline
\end{tabular}

In general, navel orange harbored the highest numbers of $M$. cartusiana followed by Egyptian clover, cabbage, lettuce and pea and while wheat, broad bean showed the lowest numbers. The total counted snails on these crops in the two successive growing seasons were $(269.4,284.8),(216,223.8),(213.4,214.0),(189.2$, $194.8),(150.1,153.2),(98.6,108.6)$ and $(84.6,87.0)$, respectively. Population density values, of $M$. cartusiana on the tested crops were higher than in the later growing season 2008-2009 compared to those counted in the first growing season of 20072008. Generally, it could be concluded that the population density of $M$. cartusiana obviously increased during spring months (Mar., Apr. and May) as compared to population density during winter and autumn months for winter crops.

Our results of population dynamics on different crops at Abo-Kapeer and Awlad-Sakr districts are very similar to results reported by many authors. 
El-Deeb et al., (1999) and Ismail (1997) indicated that the highest population density values of $M$. cartusiana were found during spring months as compared with other ones. Also, Abdel-Aal (2001) reported that the population density of M. cartusiana increased during spring months. Ismail (2004) recorded that the population density of E. vermiculata on navel orange fluctuated on soil surface and tree trunks during the year months.

The relation between population densities of M.cartusiana and both ambient temperature and relative humidity is presented in Table 3.Results revealed inconsistent and insignificant negative correlation values in most cases. These relations reflected increase of population densities in negative accordance with temperature decrease (which is not acceptable scientifically).In the mean time these densities can be correlated to winter crops growth pattern.

Table (3): Effect of temperature and relative humidity on population density of $M$. cartusiana on different crops at Awlad-Sakr district,Sharkia Governorate.

\begin{tabular}{|c|c|c|c|c|}
\hline \multirow{2}{*}{ Host plant } & \multicolumn{2}{|c|}{ Temperature } & \multicolumn{2}{|c|}{ Relative humidity\% } \\
\hline & $2007 / 2008$ & $2008 / 2009$ & $2007 / 2008$ & $2008 / 2009$ \\
\hline Egyptian clover & $-0.135^{\mathrm{n} . \mathrm{s}}$ & $0.162^{\mathrm{n} . \mathrm{s}}$ & $-0.667 *$ & $-0.595^{\mathrm{n} . \mathrm{s}}$ \\
\hline Wheat & $0.324^{\mathrm{n} . \mathrm{s}}$ & $0.392^{\mathrm{n} . \mathrm{s}}$ & $-0.866^{*}$ & $-0.585^{\mathrm{n} . \mathrm{s}}$ \\
\hline Broad bean & $0.116^{\mathrm{n} . \mathrm{s}}$ & $0.726^{\mathrm{n} . \mathrm{s}}$ & $-0.316^{\mathrm{n} . \mathrm{s}}$ & $-0.720^{\mathrm{n} . \mathrm{s}}$ \\
\hline Pea & $-0.897 *$ & $-0.813 *$ & $-0.121^{\mathrm{n} . \mathrm{s}}$ & $0.123^{\text {n.s }}$ \\
\hline Lettuce & $-0.681^{\mathrm{n} . \mathrm{s}}$ & $-0.416^{\mathrm{n} . \mathrm{s}}$ & $-0.066^{\mathrm{n} . \mathrm{s}}$ & $-0.037^{\mathrm{n} . \mathrm{s}}$ \\
\hline Cabbage & $-0.587^{\mathrm{n} . \mathrm{s}}$ & $-0.069^{\mathrm{n} . \mathrm{s}}$ & $-0.242^{\mathrm{n} . \mathrm{s}}$ & $-0.624^{\mathrm{n} . \mathrm{s}}$ \\
\hline Navel orange & $-0.639 *$ & $0.021^{\mathrm{n} . \mathrm{s}}$ & $0.088^{\mathrm{n} . \mathrm{s}}$ & $-0.650 *$ \\
\hline
\end{tabular}

\section{3- Importance value of land snail species at Inshas locality, Belbeis district, Sharkia Governorate:}

The object of this study was to characterize communities of land snail species infesting citrus orchard at Inshas locality, Belbeis district, Sharkia Governorate using some ecological parameters (i.e. frequency of occurrence, population density and biomass). Resultes in Table (4) indicated that according to frequency of occurrence, M. cartusiana was the most frequently species followed by E. vermiculata $>H$. vestalis $>C$. acuta. The percent absolute frequencies of occurrence were 93.30, 62.85, 34.28 and 28, 57, respectively.

Consequently, relative frequency of occurrence showed the same trend. Regarding population density it was found that E. vermiculata have the highest value (47.56) followed descendingly by C. acuta (27.03), M. cartusiana (21.45) and H. vestalis (3.95) snails per sample size.

According to biomass criteria E. vemiculata weighted 3.982 followed by $M$. cartusiana $(0.475)>H$. vestalis $(0.425)>C$. auta. $(0.220) \mathrm{gm} /$ snail. Consequently, relative biomass showed the same arrangement. Descending order of land snail species as evaluated by frequency occurrence, population density, biomass and importance value showed different arrangement. For example, M. cartusiana was the first one according to frequency of occurrence, while it was the third according to population density and the second according to biomass. On contrary, C. acuta jumping from the fourth to the second based on frequency occurrence and population density, respectively.

Moreover, E. vermiculata changed its position from the second according to frequency of occurrence to the first based on population density, biomass and importance value, respectively. Since frequency of occurrence, population density showed different results, they can combine together in hope of having a figure that would relate aspects of the 
three parameters. Therefore, the relationship of the three parameters was calculated as importance value according to Norton (1978). It could be concluded that the land snail species at Inshas locality, Belbeis district could be arranged descendingly according to its importance value as follow: E. vermiculata $>M$. cartusiana $>C$. acuta $>H$. vestalis. Generally, to determine relative importance of many pest species with the same feeding habits and belonging to the same taxonomic group it may be useful to combine frequency of occurrence, population density and biomass in the form of important values. Our obtained results were in a broadly similar to the findings of Mahrous et al. (2002) who evaluate the different arrangement of land snail species by frequency of occurrence, population density and biomass. Therefore, the relationship of the three parameters was calculated as importance value.

Table (4): Importance value of certain land snails at Inshas locality, Belbeis district, Sharkia Governorate.

\begin{tabular}{|l|c|c|c|c|c|c|c|}
\hline \multirow{2}{*}{ Snail species } & \multicolumn{2}{|c|}{$\begin{array}{c}\text { Frequency of } \\
\text { occurrence }\end{array}$} & \multicolumn{2}{|c|}{ Population density } & \multicolumn{2}{|c|}{ Biomass (gm) } & \multirow{2}{*}{ Importance value } \\
\cline { 2 - 8 } & Absolute & $\begin{array}{c}\text { Relative } \\
(\%)\end{array}$ & Absolute & $\begin{array}{c}\text { Relative } \\
(\%)\end{array}$ & Absolute & $\begin{array}{c}\text { Relative } \\
(\%)\end{array}$ & \\
\hline E. vermiculata & 62.85 & 28.69 & 13.30 & 47.56 & 3.982 & 78.03 & 154.3 \\
\hline M. cartusiana & 93.30 & 42.60 & 4.04 & 21.45 & 0.475 & 9.32 & 73.37 \\
\hline H. vestalis & 34.28 & 15.65 & 2.02 & 3.95 & 0.425 & 8.33 & 27.93 \\
\hline C. acuta & 28.57 & 13.04 & 16.63 & 27.03 & 0.220 & 4.32 & 44.39 \\
\hline
\end{tabular}

\section{REFERENCES}

AbdEl-Aal, S.M. (2001). Studies on certain land snails at Sharkia Governorate. M. Sc. Thesis, Fac. Agric. Zagazig. UNiv., 137pp.

Abd El-Aal. E. M. (2007). Ecological, biological and control studies on certain land snail species in Sharkia Governorate. Ph. D. Thesis. Fac. Agric. Zagaizg Univ. $185 \mathrm{pp}$.

Arafa. A. A. I (1997). Studies on some land malluscs at Sharkia Governorate. M. Sc. Thesis Fac. Agrice. Al-Azhar Univ. 137 pp.

Baker, G. H. (1988). The life history, population dynamics and polymorphism of Cernuella virgata ( Mollusca: Helicidae). Aust. J. Zool, 36, 497-512.

Barker, G. M. (2002). Molluscs as crop pests. CAB, International, Walling Forti Oxon 10 DE.UK, 468 pp.

Costat Ver.6. 311, Copyright (C) 1998- 2005, cohort software. CA, 93940, USA.

El- Deeb, H. I.; Wilson, M. and Eshra, E. H. (1999). Ecological studies on certain land snails infesting some economic crops at Behera Governorate, Egypt. Second Int. Conf. of Pest Control, Mansoura, Egypt, Sept., 1999; 19-27.

El-Masry, S. A. (1997). Studies on the control of some land snails infesting certain fruit trees. $\mathrm{Ph}, \mathrm{D}$, Thesis, Fac. Agric. Zagazig Univ, $150 \mathrm{pp}$.

El-Okda, M.M.K. (1984). Land molluscs infestation and chemical control in ElIsmailia Governorate. J. Agric. Res. Rev., 62(1): 87-92.

Ghamry, E.M.; El-Deeb, H. I. and. Kokab, Y.A. (1993). Ecological and morphological studies on certain land snails at Sharkia Governorate, Egypt. J. Appl. Sci., 8(11): 213-225.

Godan, D. (1983). Pest slugs and snails, biology and control. Spinger- Verlage, Berlin, Heidelberg: $445 \mathrm{pp}$.

Hegab, A.M.; Ghamry, E.M.; El-Masry, S.A. and Hassan, A.I. (1999). Ecological studies on certain land snails in some localities at Sharkia Governorate, Zagazig. J. Agric. Res., 26(3B): 787-795. 
Ismail, Sh. A. (1997). Ecology, biology and control of certain terrestrial snails infesting some vegetables and field crops in Sharkia Governorate. Ph.D. Thesis. Fac. Agric. Zagazig Univ.128 pp.

Ismail, Sh. A. (2004). Ecobiological studies on the brown garden snail, Eobania vermiculata (Muller) under laboratory and field conditions in Sharkia Governorate. Zagazig. J. Agric. Res., 31 (1): 293 - 305.

Kassab, A and Daoud, H. (1964). Notes on the biology and control of land snails of economic importance in the U.A.R. J. Agric. Res. Rev. 42: 77: 98.

Lokma, M. H. E. (2007). Studies on some terrestrial gastropods injurious to field crops at Sharkia Governorate. M.Sc. Thesis, Fac. Zagazig Univ., 147 pp.

Mahrous, M. E.; Ibrahim. M. H. and Abd El-Aal, E.M. (2002). Occurrence, population density and importance value of land snails infesting different crops in Sharkia Governorate. Zagazig J. Agric. Res., 29 (2): 613 - 629.

Mahrous, M.E; Ibrahim. M. H and Abd El-Aal, E.M. (2002). Ecological aspects of the glassy clover snail, Monacha cartusiana (Muller), under field conditions in Sharkia Governorate, Egypt. $2^{\text {nd }}$. Inter. Conf. PPRI. Cairo, Egypt, 21-24 December, 1:107-114.

Norton, D.C. (1978): Ecology of plant-parasitic nematodes. Wiley, NewYork, 268 pp.

Staikou, A. and Lazaridou-Dimitriadou, M. (1990). Aspects of the life cycle, population dynamics, growth and secondary production of the snail, Monacha cartusiana (Muller, 1884) (Gastropoda; Pulmonata) in Greece. Malacologia, 31(2): 353-362.

\section{ARABIC SUMMARY}

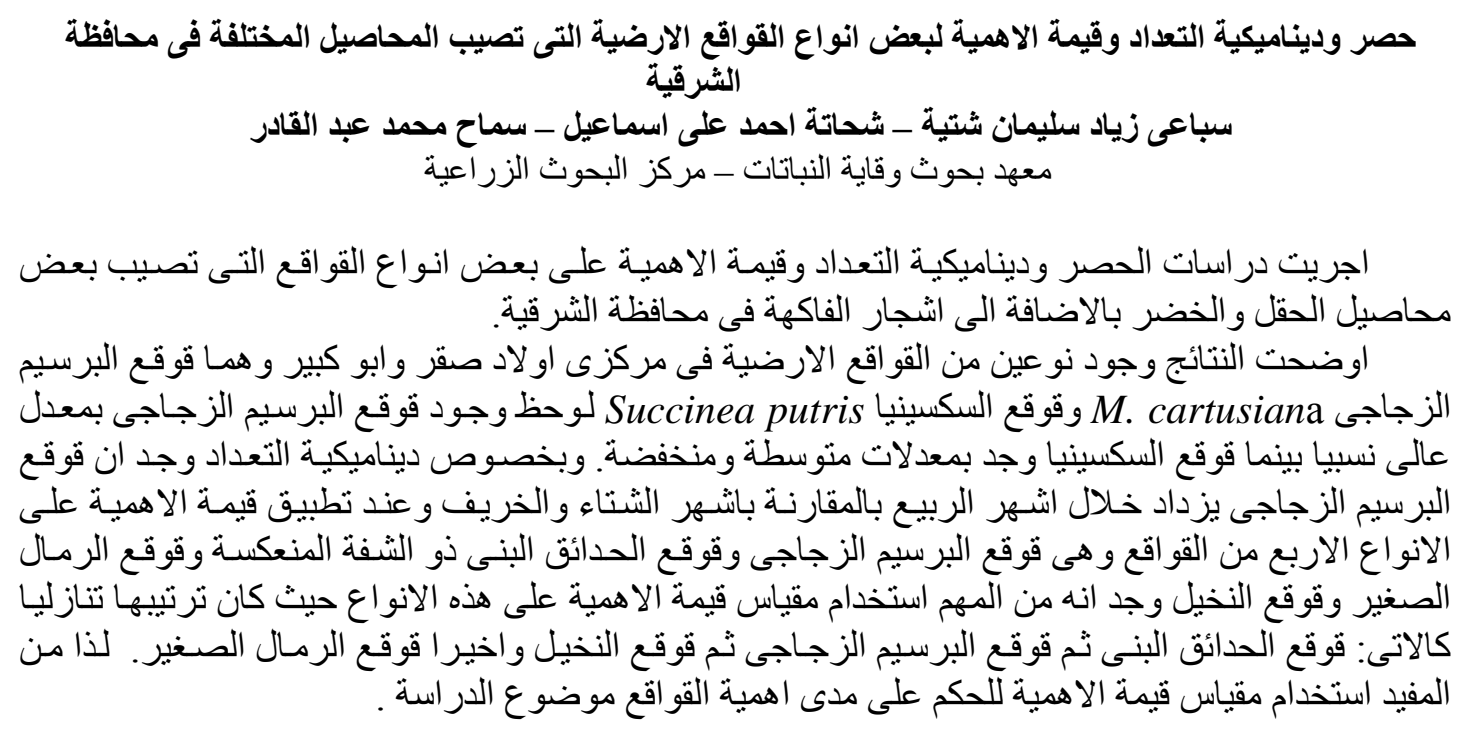

